\title{
Bacterial siderophores efficiently provide iron to iron-starved tomato plants in hydroponics culture
}

\author{
W. Radzki • F. J. Gutierrez Mañero • \\ E. Algar · J. A. Lucas García · \\ A. García-Villaraco • B. Ramos Solano
}

Received: 22 April 2013/Accepted: 15 June 2013/Published online: 29 June 2013

(C) The Author(s) 2013. This article is published with open access at Springerlink.com

\begin{abstract}
Iron is one of the essential elements for a proper plant development. Providing plants with an accessible form of iron is crucial when it is scant or unavailable in soils. Chemical chelates are the only current alternative and are highly stable in soils, therefore, posing a threat to drinking water. The aim of this investigation was to quantify siderophores produced by two bacterial strains and to determine if these bacterial siderophores would palliate chlorotic symptoms of iron-starved tomato plants. For this purpose, siderophore production in MM9 medium by two selected bacterial strains was quantified, and the best was used for biological assay. Bacterial culture media free of bacteria (S) and with bacterial cells (BS), both supplemented with Fe were delivered to 12-week-old plants grown under iron starvation in hydroponic conditions; controls with full Hoagland solution, ironfree Hoagland solution and water were also conducted. Treatments were applied twice along the experiment,
\end{abstract}

W. Radzki

Department of Fruits, Vegetables and Mushrooms

Technology, Faculty of Food Sciences and

Biotechnology, Life Sciences University in Lublin,

ul. Skromna 8, 20-704 Lublin, Poland

e-mail:wpradzki@gmail.com

W. Radzki · F. J. Gutierrez Mañero ·

E. Algar · J. A. Lucas García · A. García-Villaraco .

B. Ramos Solano ( $\square)$

Facultad de Farmacia, Universidad San Pablo CEU, Ctra Boadilla del Monte km 5.3, 28668 Madrid, Spain

e-mail: bramsol@ceu.es with a week in between. At harvest, plant yield, chlorophyll content and nutritional status in leaves were measured. Both the bacterial siderophore treatments significantly increased plant yield, chlorophyll and iron content over the positive controls with full Hoagland solution, indicating that siderophores are effective in providing Fe to the plant, either with or without the presence of bacteria. In summary, siderophores from strain Chryseobacterium C138 are effective in supplying Fe to iron-starved tomato plants by the roots, either with or without the presence of bacteria. Based on the amount of siderophores produced, an effective and economically feasible organic Fe chelator could be developed.

Keywords Iron · Siderophores ·

Plant growth-promoting rhizobacteria (PGPR) .

Biofertilizer - Tomato $\cdot$ Bacterial chelator

\section{Introduction}

Iron is a crucial element for proper plant development. Since it is a cofactor of many metabolic pathways its deficiency may lead to disruption of many processes including respiration or photosynthesis and be the reason for a chlorosis in the aftermath (Guerinot 2010; Zuo and Zhang 2011). Iron is the fourth most abundant element in the earth's crust and in most types of soil occurs in excess. This element can exist in aqueous solution in two states: $\mathrm{Fe}^{2+}$ and $\mathrm{Fe}^{3+}$; however, $\mathrm{Fe}^{3+}$ 
forms are not readily utilizable by plants and microbes because they often form insoluble oxides or hydroxides which limit bioavailability (Desai and Archana 2011; Zuo and Zhang 2011). It is estimated that approximately one-third of earth's soil can be considered iron deficient (Yi et al. 1994).

Plants use two strategies to acquire iron. Strategy I involves acidification of the rhizosphere followed by reduction of $\mathrm{Fe}^{3+}$ ions by membrane-bound $\mathrm{Fe}$ (III)chelate reductase and subsequent uptake of $\mathrm{Fe}^{2+}$ into root cells. Strategy II refers to the plants which secrete low molecular weight phytosiderophores in order to solubilise and bind iron which is then transported into root cells via membrane proteins (Altomare and Tringovska 2011; Guerinot 2010). However, these strategies are often not efficient enough to meet the needs of the plants growing especially in calcareous and alkaline soils. Therefore, providing plants with accessible forms of iron is necessary when it is scant or unavailable in soils (Zuo and Zhang 2011).

The amount of iron absorbed by plants is also important for human health. According to World Health Organization, approximately two billion people around the world are anaemic, mainly due to iron deficiency. This problem could be approached by consumption of iron-rich fruits and vegetables (www. who.int/nutrition/topics/ida/en/index.html). Tomato ranks third by weight in global production of fruits and vegetables and tomato fruits or products are widely consumed all over the world reaching $40 \mathrm{~kg}$ per capita on average in the United States (Tan et al. 2010). Tomato fruits possess high nutritional value as a source of many essential minerals and vitamins like vitamin $\mathrm{C}$, vitamin $\mathrm{E}$, folate and potassium. It also contains substantial amounts of carotenoids, especially lycopene and $\beta$-carotene which have high antioxidant potential and contribute to anticancer activity (Adalid et al. 2010; Campbell and Erdman 2005; Tan et al. 2010).

Generally, there are two main strategies to deliver iron to the plants-soil and crop management. Crop management practices involve foliar and root delivery of iron in inorganic form $\left(\mathrm{FeSO}_{4}\right)$ or as synthetic or non-synthetic Fe-chelates (Fernández et al. 2005; Godsey et al. 2003). It is noteworthy that applying Fechelates to leaves usually gives more satisfactory results compared to an inorganic form of iron (Vempati and Loeppert 1988). Soil management may involve fertilizing with inorganic salts $\left(\right.$ as $\mathrm{NO}_{3}{ }^{-}$or $\mathrm{NH}_{4}{ }^{+}$) in order to change $\mathrm{pH}$, thus improving iron solubility and increasing its uptake by the plants (Zuo and Zhang 2011). A second way of soil management is based on delivering iron to soil as chelates or $\mathrm{FeSO}_{4}$. However, using synthetic chelates like Fe-EDTA or Fe-EDDHA is cheaper and more effective (Shenker and Chen 2005) but their overuse may have negative environmental impacts (Adesemoye et al. 2009).

Another method of fertilizing soil, which is currently gaining importance since it is considered environmentally friendly, is the application of inoculants containing one or more beneficial microorganisms known as plant growth-promoting rhizobacteria (PGPR). Among the benefits for plant fitness attributed to PGPR is the ability to release siderophores, compounds below $2 \mathrm{kDa}$ capable of chelating Fe with high affinity and in a reversible manner (Budzikiewicz 2010; Neilands 1995). The functional groups responsible for the binding are most frequently hydroxymates and catechols (Raymond et al. 1984). Many studies demonstrated that microbial siderophores are used by plants (Crowley et al. 1992; Fernández et al. 2005; Johnson et al. 2002). Furthermore, many PGPR strains exert additional beneficial effects on the plants apart from improving iron nutrition, since they are able to solubilise phosphates and other micronutrients in soil (Ramos Solano et al. 2008). Moreover, some PGPR are able to release molecules identical to plant growth regulators, that are absorbed by the plant and, therefore, may cause increases in root surface, and subsequent enhanced nutrient uptake (Adesemoye et al. 2009; Ramos Solano et al. 2008; Ramos-Solano et al. 2010). However, the use of biofertilizers is not consistent yet in any field condition since bacterial genes are highly inducible and a number of factors may affect bacterial performance (Rainey 1999). Therefore, in order to overcome potential bacterial failure, the use of bacterial metabolites appears as an encouraging alternative.

The aims of this work were, therefore, (i) first, to evaluate bacterial siderophore production of two PGPR strains in vitro and (ii) to assess the effect of bacterial siderophores supplemented with iron alone (metabolite) and in combination with the PGPR (metabolite + cells) to overcome iron deficiency on iron-starved tomato plants (Lycopersicon esculentum var. Marglobe). 


\section{Materials and methods}

Bacterial strains

Two siderophore-producing bacterial strains were studied; Chryseobacterium spp. C138 isolated from the rhizosphere of Oryza sativa (unpublished) and Pseudomonas fluorescens N21.4 from the rhizosphere of Nicotiana glauca (Ramos-Solano et al. 2010). Strains were kept on Triptone Soy Broth (TSB) amended with $15 \%$ glycerol at $-20{ }^{\circ} \mathrm{C}$. Prior to experiment, bacteria were streaked on plate count agar (PCA) plates and grown for $24 \mathrm{~h}$ at $28{ }^{\circ} \mathrm{C}$.

Siderophore production media, quantitative determination and iron-binding capacity

Bacterial strains were grown in modified M9 medium (MM9) without added iron (Alexander and Zuberer 1991). The composition of this media was $\mathrm{KH}_{2} \mathrm{PO}_{4}$ $0.3 \mathrm{~g}, \mathrm{NaCl} 0.5 \mathrm{~g}, \mathrm{NH}_{4} \mathrm{Cl} 1 \mathrm{~g}, \mathrm{MgSO}_{4} \cdot 7 \mathrm{H}_{2} \mathrm{O} 493 \mathrm{mg}$, $\mathrm{CaCl}_{2} 11 \mathrm{mg}, \mathrm{MnSO}_{4} \cdot \mathrm{H}_{2} \mathrm{O} 1.17 \mathrm{mg}, \mathrm{H}_{3} \mathrm{BO}_{3} 1.4 \mathrm{mg}$, $\mathrm{CuSO}_{4} \cdot 5 \mathrm{H}_{2} \mathrm{O} \quad 0.04 \mathrm{mg}, \quad \mathrm{ZnSO}_{4} \cdot 7 \mathrm{H}_{2} \mathrm{O} \quad 1.2 \mathrm{mg}$, $\mathrm{Na}_{2} \mathrm{MoO}_{4} \cdot 2 \mathrm{H}_{2} \mathrm{O} 1 \mathrm{mg}$, casamino acids $3 \mathrm{~g}$, PIPES $30.24 \mathrm{~g}, \mathrm{FeCl}_{3} \cdot 6 \mathrm{H}_{2} \mathrm{O} 10 \mu \mathrm{M}$, EDTA $3.27 \mathrm{mg}$ and glycerol $5 \mathrm{~g}$. Siderophores were measured using modified chromeazurol S (CAS) assay (Alexander and Zuberer 1991). Deferoxamine mesylate (DFOM) (Sigma-Aldrich) was used as a standard to construct the calibration curve. Serial dilutions of the standard were mixed with CAS assay solution $(1 / 1 \mathrm{v} / \mathrm{v})$ and incubated for $4 \mathrm{~h}$ at $25{ }^{\circ} \mathrm{C}$, prior to the spectrophotometric measurement at $630 \mathrm{~nm}$ done by double-beam UV-Vis spectrophotometer (Thermo, Biomate). Results are expressed as $\mu \mathrm{M}$ equivalents of DFOM. To calculate the iron-binding capacity of bacterial siderophores, $1 \mathrm{mmol}$ of DFOM is considered to be able to bind $56 \mathrm{mg} \mathrm{Fe}^{3+}$.

\section{Quantification of bacterial siderophores}

For each strain, a pre-inoculum was prepared from a 24-h grown PCA plate suspended in $10 \mathrm{mM}$ magnesium sulphate buffer $\mathrm{pH} 6.8$, with an optical density of 0.7 at $600 \mathrm{~nm}$. One $\mathrm{mL}$ of the suspension was transferred to $250 \mathrm{~mL}$ Erlenmeyer flasks containing $100 \mathrm{~mL}$ of the MM9 media described above. Flasks were shaken at $175 \mathrm{rpm}$ for $72 \mathrm{~h}$ at $28{ }^{\circ} \mathrm{C}$.
Bacterial growth parameters (optical density at $600 \mathrm{~nm}, \mathrm{pH}$ ) and siderophore content were checked 3 times per day, at 3-h intervals. Prior to each determination, culture media were centrifuged at $4,000 \mathrm{rpm}$ for $10 \mathrm{~min}$ at $4{ }^{\circ} \mathrm{C}$ and filtered through $0.2 \mu \mathrm{m}$ (Millipore) to remove bacterial cells. Samples were stored at $-20{ }^{\circ} \mathrm{C}$ until analysis. UV-Vis spectra of the culture supernatants, withdrawn after $44 \mathrm{~h}$, were recorded on double-beam spectrophotometer (Biomate, Thermo) in the range of $220-500 \mathrm{~nm}$. Siderophore content in bacterial supernatants was measured as described in "Siderophore production media, quantitative determination and iron-binding capacity" section, and absorbance values at $630 \mathrm{~nm}$ were interpolated on the calibration curve.

Production of iron-bound bacterial siderophores

For the biological assay, 1 L of MM9 media was inoculated with $1 \mathrm{~mL}$ of bacterial suspension $\left(10^{8} \mathrm{cfu} \mathrm{mL}^{-1}\right)$. Flasks were shaken for $42 \mathrm{~h}$ at $28^{\circ} \mathrm{C}$ at $175 \mathrm{rpm}$ to allow siderophore production. Then, $500 \mathrm{~mL}$ was devoted to obtain siderophores alone (S) and $500 \mathrm{~mL}$ for siderophores and bacterial cells (SB). For siderophores alone (S), media were centrifuged at $4,000 \mathrm{rpm}$ at $4{ }^{\circ} \mathrm{C}$ and filtered to remove bacterial cells. The second part (SB) contained siderophores and bacterial cells $\left(10^{9} \mathrm{cfu} \mathrm{mL}^{-1}\right)$. Siderophore content was checked as described in "Siderophore production media, quantitative determination and ironbinding capacity" section. Then, both parts were incubated with $19 \mu \mathrm{M}$ of $\mathrm{FeCl}_{3} \cdot 6 \mathrm{H}_{2} \mathrm{O}$ for $90 \mathrm{~min}$ at room temperature, to provide an equivalent amount of iron present in full Hoagland solution $(1.064 \mu \mathrm{g} / \mathrm{mL})$.

\section{Experimental design}

Tomato seeds of Lycopersicon esculentum var. Marglobe were used. Plants were grown in a greenhouse under controlled conditions $(15 / 9 \mathrm{~h}$ light/dark, $25 / 20{ }^{\circ}$ C, R.H $20-70 \%$ ). Seeds were sown in $100 \mathrm{~mL}$ pots filled with sterile sand; pots were covered with plastic to ensure proper humidity for germination. When seedlings emerged, plastic wrap was removed and seedlings were watered with $10 \mathrm{~mL}$ per day; to ensure plant growth and chlorosis development, water was replaced by iron-free Hoagland solution every 3 days throughout the experiment. After 14 days, seedlings were divided into 5 groups $(n=9)$. 
Thirty-five days after the emergence, when the upper leaves turned yellow, treatments were delivered as follows: full Hoagland solution (positive control), iron-free Hoagland solution (negative control), siderophores $(\mathrm{S})+\mathrm{Fe}$ and siderophores and bacteria (SB) + Fe; the fifth group was kept only with water as a second negative control. Treatments $(10 \mathrm{~mL})$ were delivered twice, with a week in between. Seven days after treatment delivery, plants were harvested and dried for further nutrient determination. The following determinations were done: biometrical analyses (shoot length and stem diameter, shoot dry weight) and chlorophyll content determination.

For nutritional analyses, plants from each treatment were pooled, and analyses were carried out on the mixture of expanded upper leaves of each plant. Total $\mathrm{N}$ was analyzed by Kjeldhal digestion. Concentrations of $\mathrm{P}, \mathrm{S}, \mathrm{Ca}, \mathrm{Mg}, \mathrm{K}, \mathrm{Fe}, \mathrm{Mn}$ and $\mathrm{Al}$ were determined by $\mathrm{HNO}_{3}$ /pressure digestion as described by Chander et al. (2008), followed by ICP-AES analysis (Spectro Analytical Instruments, Kleve, Germany). Nutritional analyses were carried out by Albion Laboratories.

\section{Chlorophyll determination}

Chlorophyll content was determined on the last fully expanded leaf of plants from each treatment. Determination was done according to Lichtenthaler and Buschmann (2001). Chlorophyll was extracted with methanol from a stripe cut from a fully expanded upper leaf of each plant homogenized with a blender and the absorbance was measured at 665 and $652 \mathrm{~nm}$.

\section{Statistical analysis}

The results were statistically tested using unidirectional analysis of variance ANOVA with a level of significance set at $\alpha=0.05$. When differences were significant a Tukey test $(p<0.05)$ was performed with the computer programme Statgraphics plus 5.1, for WindowsTM.

\section{Results}

Bacterial growth and siderophore production

Siderophore production increased as bacterial biomass increased after $16 \mathrm{~h}$ of culture; the greatest accumulation of siderophores occurred at the stationary phase, after $40 \mathrm{~h}$ by strain N21.4, and after $72 \mathrm{~h}$ by strain C138 (Fig. 1). While strain C138 accumulated up to $425 \mu \mathrm{mol}$ equivalents of DFOM in $72 \mathrm{~h}$; strain N21.4 achieved lower production, reaching $300 \mu \mathrm{mol}$ equivalents of DFOM in $40 \mathrm{~h}$. During the incubation period, $\mathrm{pH}$ decreased with $\mathrm{C} 138$ by $1.4 \mathrm{U}$ to values of 5, while it remained constant around 6.6 in N21.4 cultures. Siderophore production by $\mathrm{C} 138$ was more abundant and, therefore, it was selected for further experiments.

UV-Vis spectra of bacterial culture filtrates revealed that the nature of the siderophore produced by each strain was different, while $\mathrm{C} 138$ filtrate does not absorb light in visible region while N21.4 does (Fig. 2).

\section{Biometrical analysis}

Data obtained from biometrical analysis of tomato plants appear in Fig. 3. Bacterial siderophores with (BS) or without bacteria (S), both supplemented with $\mathrm{Fe}$ affected biometrical features of plants. Values of stem diameter and shoot dry weight were significantly higher in treated plants than in the negative controls (iron-free Hoagland solution and water). Stem diameter (Fig. 3b) reached almost the same values $(3.8 \mathrm{~mm})$ with both bacterial treatments (S and BS) and only the S treatment was significantly higher than that obtained on plants watered with full Hoagland solution; no significant differences appeared between both negative control treatments (water-treated plants and iron-free Hoagland). Shoot length and weight were affected differentially by the siderophore (S) or the bacteria (BS). Shoot length (Fig. 3a) averaged $17 \mathrm{~cm}$ in iron-supplied plants ( $\mathrm{S}, \mathrm{BS}$ and $\mathrm{H}$ ) being highest in plants treated with the siderophore (S). Conversely, shoot dry weight was highest on bacterial (BS)-treated plants $(0.6 \mathrm{~g})$ and significantly different from full Hoagland solutiontreated plants $(0.5 \mathrm{~g})$. Interestingly, delivering living bacteria (BS) to the plants resulted in a significant increase in shoot dry weight, comparing to full Hoagland solution-treated plants $(\mathrm{H})$.

\section{Chlorophyll content}

Chlorophyll content analysis showed non-significant differences in total chlorophylls between siderophore treatments (S or BS) and the Hoagland-treated plants 
Fig. 1 Growth parameters (bacterial density and $\mathrm{pH}$ ) and siderophore production ( $\mu \mathrm{mol} \mathrm{L}{ }^{-1}$ DFOM

equivalent) by strains $\mathrm{C} 138$ (a) and N21.4 (b). Data are given as mean $\pm \mathrm{SD}, n=3$
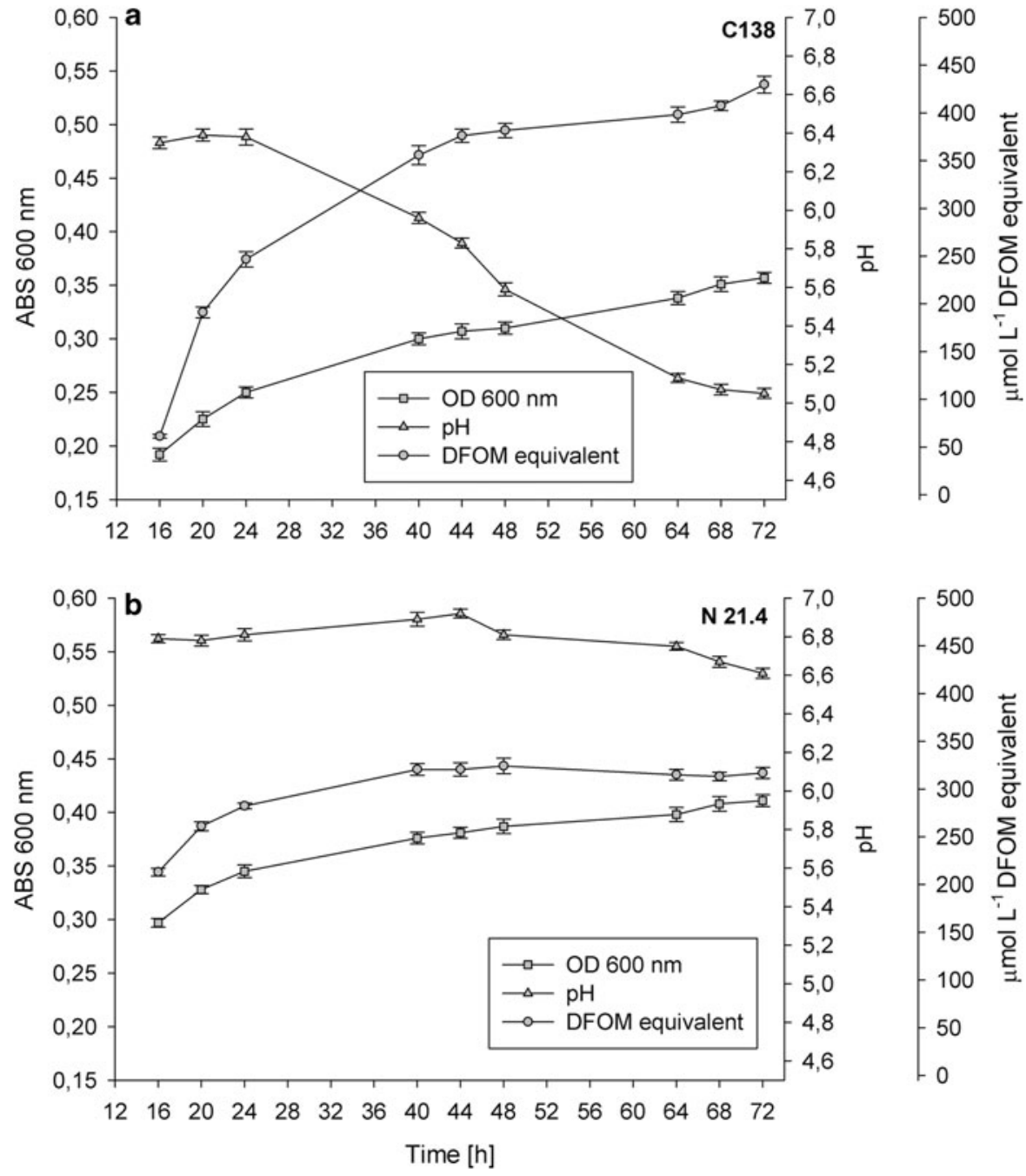

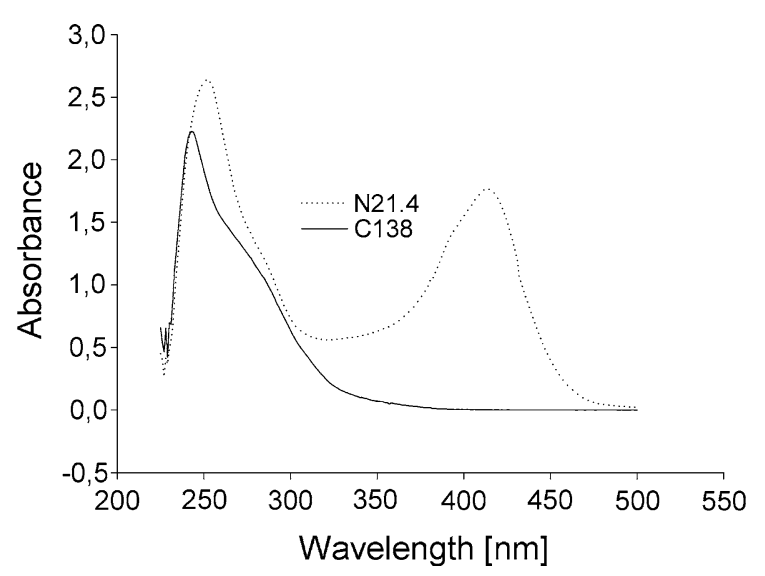

Fig. 2 UV-Vis spectra of C138 and N21.4 siderophore-rich culture filtrates
(Fig. 4), being the highest values in full Hoagland solution $(\mathrm{H})$-treated plants.

The nutritional status of plants is shown in Fig. 5. BS- and S-treated plants contained the highest levels of iron (62 and $60 \mathrm{ppm}$, respectively), compared to full Hoagland solution-treated plants (53 ppm). The amounts of copper, boron, aluminium and sodium were highest in S-treated plants. Interestingly, aluminium uptake was moderate under bacterial influence and peaked on S-treated plants.

\section{Discussion}

Iron is an essential element for plants, and, therefore, it is absolutely necessary to close plant cycle. 

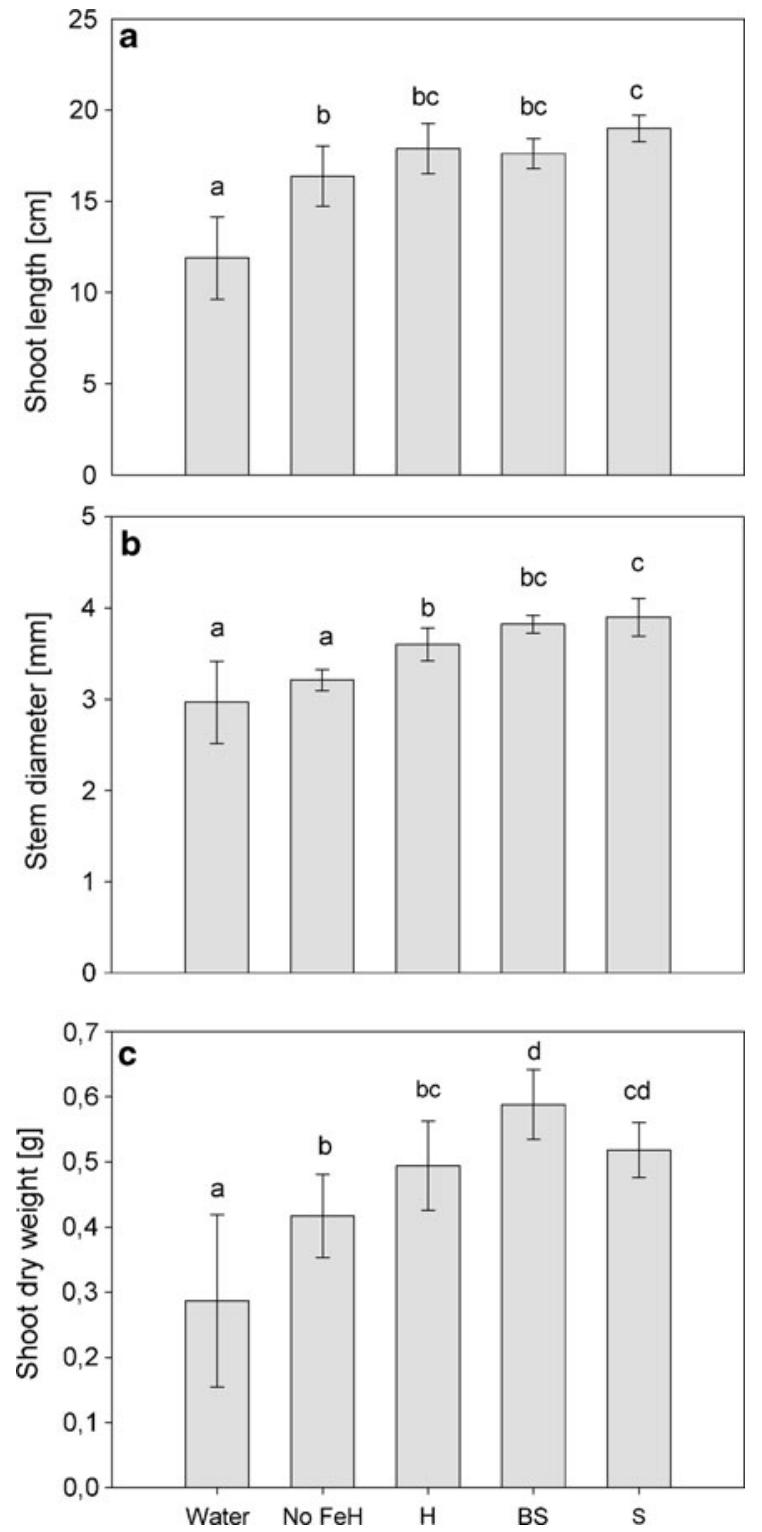

Fig. 3 Biometrical parameters a shoot length $(\mathrm{cm})$, b stem diameter $(\mathrm{mm})$ and $\mathbf{c}$ shoot dry weight $(\mathrm{g})$ of 70-day-old ironstarved tomato plants treated with C138 siderophores (S) and the siderophores + bacteria (BS), both supplemented with iron, and control plants (Water), full Hoagland solution $(\mathrm{H})$, iron-free Hoagland solution (No FeH), 7 days after the second dose. Data represent mean values of nine replicates \pm SE. Different letters indicate the existence of significant differences according to Tukey test $(\alpha=0.05)$

Hence, relevance in agriculture is beyond any doubt, especially since its solubility is conditioned by $\mathrm{pH}$. Iron deficiency has an important economic impact on the fruit sector because it can reduce fruit yield and

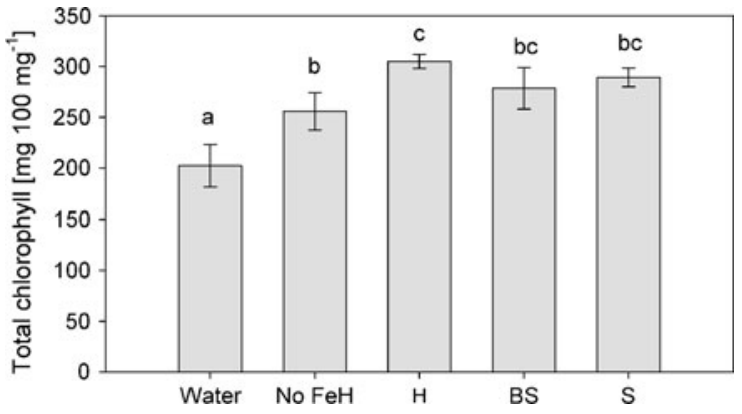

Fig. 4 Total chlorophyll content in 70-day-old iron-starved tomato plants treated with $\mathrm{C} 138$ siderophores (BS) and the siderophores (S), both supplemented with iron, and control plants (Water), full Hoagland solution $(\mathrm{H})$, iron-free Hoagland solution (no FeH), 7 days after the second dose. Data represent mean values of nine replicates \pm SE. Different letters indicate the existence of significant differences according to Tukey test $(\alpha=0.05)$

quality (Álvarez-Fernández et al. 2006), and also because Fe fertilization is expensive (Rombolá and Tagliavini 2006). Up to the date, only synthetic chelates are available for agriculture and among these, EDTA and EDDHA are the most widely distributed (Orera et al. 2009). Both are poorly biodegradable and pose a threat to environment (Fernández et al. 2005), the main risk being the accumulation in ground water (Kaparullina et al. 2011). Although the high concentrations of EDTA itself are not toxic for humans, the main risk remains in its ability to bind heavy and toxic metals and rend them water soluble, therefore, contaminating drinking water (Kaparullina et al. 2011). Furthermore, EDTA is not easily removed during wastewater treatment (Kari and Giger 1995). In view of this, it is vital to find alternative ways to deliver iron to the plants which are sensitive to iron deficiency. Furthermore, organic farming and ecological agriculture call for a natural product able to cover up the needs in these handling procedures.

Production of siderophores is a frequent bacterial trait due to the physiological role of metals in cells, and their production is subject to metal availability/ demand (Schalk et al. 2011), and, therefore, basal production is low. In this experiment, the production of organic chelates by two PGPR strains was evaluated in an iron-free medium, seeking the induction of siderophore production. The two strains were selected for their excellent results obtained on CAS agar medium plates (Ramos-Solano et al. 2010; unpublished). After evaluating the ability of each strain to 

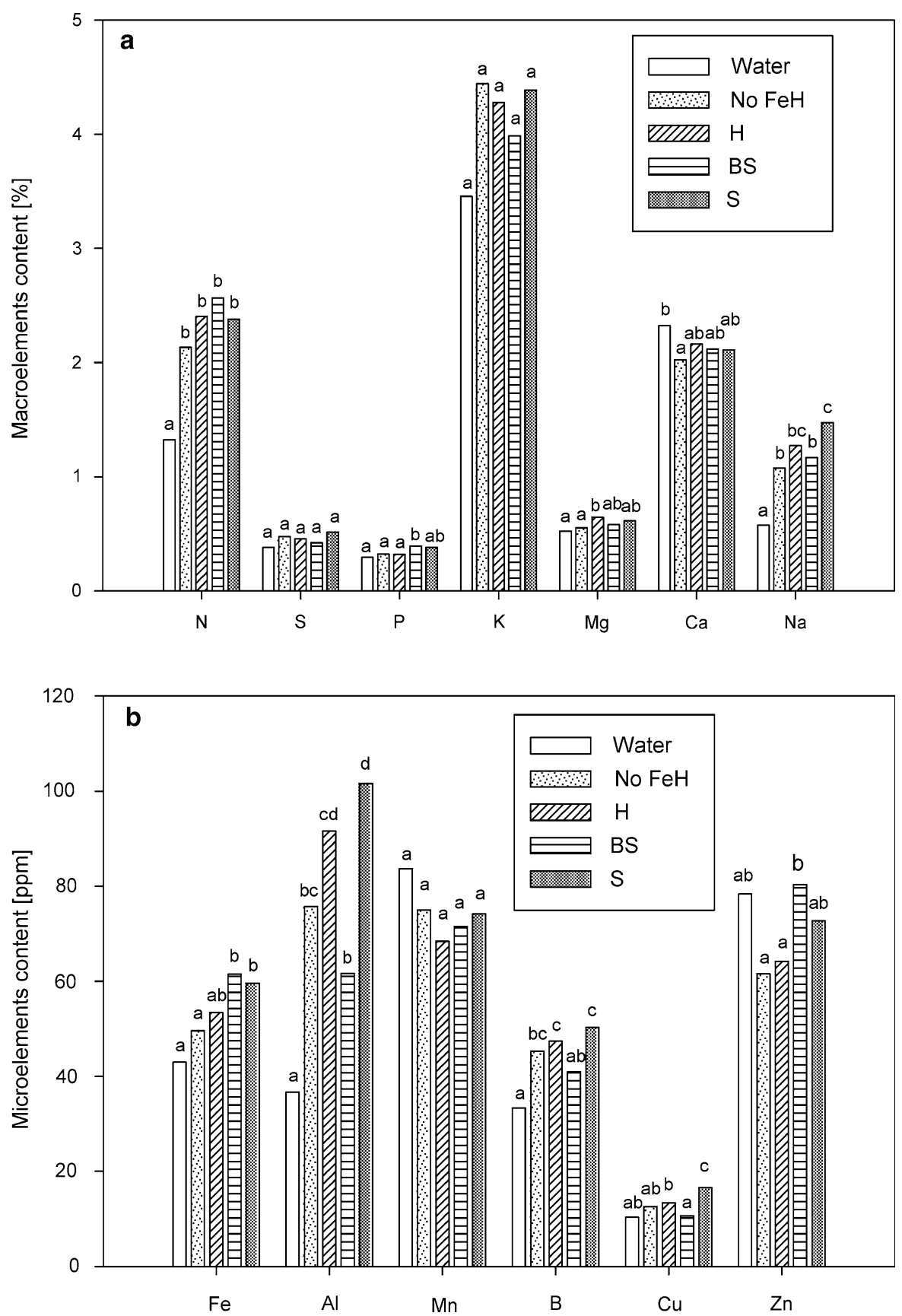

Fig. 5 Nutritional status of 70-day-old iron-starved tomato plants treated with siderophores and bacteria (BS) and siderophores (S), both supplemented with iron, and control plants (Water), full Hoagland solution (Hoagland), iron-free

release siderophores into culture media, strain C138 was able to produce high amounts of siderophores within $72 \mathrm{~h}$, and, therefore, it was selected for the biological assay on tomato plants. The yellow-orange
Hoagland solution (no $\mathrm{FeH}$ ) 7 days after the second dose. a macroelements (\%) and b microelements (ppm). Different letters indicate the existence of significant differences according to Tukey test $(\alpha=0.05)$

halos on CAS agar medium produced by $\mathrm{C} 138$ and the quick change of colour of CAS reagent suggest that it is of the catechol type (Schwyn and Neilands 1987). However, its chemical structure has not been 
determined yet. According to UV-Vis spectra of bacterial culture filtrates (Fig. 2), C138 filtrate does not absorb light in visible region compared to N21.4, which point out a difference in the chemical nature of the siderophore produced by these strains consistent with the reported structural variability for these group of compounds (Hider and Kong 2010).

Bioassay on iron-starved tomato plants revealed that iron-chelated bacterial siderophores were suitable for plants. Plants treated with bacterial chelates (S and BS) showed better growth parameters than plants deprived of any Fe source, reaching similar values than plants supplied with full Hoagland solution (Fig. 3), confirming the efficacy of bacterial siderophores. Interestingly, delivering siderophores and bacteria to plants (BS) resulted in a significant increase in shoot dry weight, compared to full Hoagland solution $(\mathrm{H})$, and higher than plants treated only with siderophores (S), indicating that the bacteria are conferring an additional benefit to the plant other than providing $\mathrm{Fe}$-chelates. Although in vitro test for auxin production or ACC degradation was recorded negative for $\mathrm{C} 138$ (unpublished), production of plant growth regulators is within the putative mechanisms of plant growth promotion. Despite the negative record for auxin production by $\mathrm{C} 138$, it is a fact that the effective amount of a plant growth regulator is conditioned by the plant species, physiological status and concentration of other plant growth regulators (Peleg and Blumwald 2011). Therefore, this strain may be altering a plant's hormonal balance, which may affect root growth patterns and, therefore, improve nutrient absorption by increasing absorption area (RamosSolano et al. 2010).

Plant dry matter was well correlated with chlorophyll concentration in the upper leaves (Fig. 4), confirming that the chlorotic symptoms evidenced prior to treatment delivery due to iron deficiency were overcome with the bacterial siderophores. Interestingly, the presence of bacteria + siderophores (BS) in plant roots caused a significant increase of shoot dry weight compared to plants treated only with siderophores (S) supporting the proposed hypothesis of the bacteria increasing absorption potential of the plant. Nutritional analysis of shoots confirmed the improved iron uptake by siderophore-treated plants. The level of $\mathrm{Fe}$ in $\mathrm{C} 138$ (BS) and C138 filtrate (S) treatments was even higher than in plants where $\mathrm{Fe}$ was provided with synthetic agent (EDDHA) in the full Hoagland solution (Fig. 5). Although the fate of the siderophore has not been evaluated yet, the similar efficiency of the organic and chemical agents appears as a promising alternative to reduce chemical inputs due to $\mathrm{Fe}$ chemical fertilization (Orera et al. 2009). A positive side effect was also observed for $\mathrm{N}, \mathrm{P}, \mathrm{K}$ and $\mathrm{Na}$, indicating that a fast recovery of nutrients was occurring in BS-treated plants (Nikolic et al. 2007); this was specially marked for $\mathrm{N}$, consistent with growth parameters, and, therefore, could have an impact in the nutritional quality of edible parts of plants (Briat et al. 2007; Tomasi et al. 2009). Since the siderophore was provided to plants with $\mathrm{Fe}$, effects should only refer to this ion. However, in addition to increased Fe levels on plants treated with the culture filtrate (S) or with the bacteria (BS), a strong side effect is evidenced for aluminium, specially marked in the case of the culture filtrate (S) as compared to the bacterial treatment (BS), and similar to that of full Hoagland solution. This supports the notion of siderophores being able to bind Fe and other metals with variable specificity (Schalk et al. 2011).

It has been described how plants follow two strategies to solubilise unavailable Fe(III) forms from soil. Strategy II refers to the plants which secrete low molecular weight phytosiderophores in order to solubilise and bind iron which is then transported into root cells via membrane proteins (Altomare and Tringovska 2011; Guerinot 2010). In addition, plants manage to select microorganisms able to release siderophores into their rhizosphere (Ramos-Solano et al. 2010), and these bacterial siderophores may be used by both organisms. However, despite its welldemonstrated effect to provide iron to plants (Crowley et al. 1992; Fernández et al. 2005; Johnson et al. 2002), the fate of bacterial siderophores is not clear. According to our results, it seems feasible that the bacterial siderophore is not absorbed by the plant, and iron is obtained through a reduction-based mechanism (Cesco et al. 2002; Hördt et al. 2000; Römheld and Marschner 1986), allowing siderophore release for subsequent re-use. This hypothesis will explain the increase in iron coupled to a higher increase in aluminium in S-treated plants (Fig. 4); since aluminium concentration is not increased in the solution, it means that there is a better efficiency in its absorption on S-treated plants, probably due to a higher affinity for aluminium. Interestingly, the presence of $\mathrm{C} 138$ with its siderophores (BS) is more efficient enhancing $\mathrm{Fe}$ absorption and preventing potential aluminium 
toxicity when delivered to the roots, and is consistent with the new role proposed for siderophores on protecting bacteria against metal toxicity (Schalk et al. 2011). However, in order to avoid ion toxicity (aluminium), Fe-bound siderophores could be delivered to the shoot system, since Fe delivery to the plants has been done effectively through the leaves for a long time (Tomasi et al. 2009; Vempati and Loeppert 1988). Furthermore, spraying Fe-free siderophores on leaves could be a way to prevent pathogen attack, based on the Fe-scavenging capacity of bacterial siderophores and the essentiality of $\mathrm{Fe}$ for other microorganisms (Duffy and Défago 1999; Schalk et al. 2011) and the reported ability of these molecules to induce systemic resistance (De Vleesschauwer et al. 2008; Meziane et al. 2005). Considering the market potential for Fe chelators $\left(200-400 € \mathrm{ha}^{-1}\right.$ year $^{-1}$ in 2006; Rombolá and Tagliavini 2006), it is worth pursuing this study to evaluate the applicability of the biological iron chelator in field trials.

\section{Conclusions}

Bacterial siderophores from $\mathrm{C} 138$ are effective in supplying $\mathrm{Fe}$ to iron-starved tomato plants when delivered to the roots, independent of the bacterial presence. Furthermore, results are similar or even better than with full Hoagland solution, representing a promising candidate to develop an organic Fe chelator. The short period needed for fermentation appears as an asset for economic feasibility. In summary, strain C138 tested in this experiment can serve as an effective organic biofertilizer.

Acknowledgments Authors wish to acknowledge EADSCASA and Airbus Military for granting WR, to the Spanish Ministry of Economy, Innovation and competitiveness for projects AGL2009-13487-C04-04/AGR, AGL2009-08324, Madrid Community CM S2009/AMB-151, and Agrichem SA.

Open Access This article is distributed under the terms of the Creative Commons Attribution License which permits any use, distribution, and reproduction in any medium, provided the original author(s) and the source are credited.

\section{References}

Adalid AM, Roselló S, Nuez F (2010) Evaluation and selection of tomato accessions (Solanum section Lycopersicon) for content of lycopene, $\beta$-carotene and ascorbic acid. J Food Compos Anal 23:613-618

Adesemoye AO, Torbert HA, Kloepper JW (2009) Plant growth-promoting rhizobacteria allow reduced application rates of chemical fertilizers. Microb Ecol 58:921-929

Alexander DB, Zuberer DA (1991) Use of chrome azurol S reagents to evaluate siderophore production by rhizosphere bacteria. Biol Fertil Soils 12:39-45

Altomare C, Tringovska I (2011) Beneficial soil microorganisms, an ecological alternative for soil fertility management. In: Lichtfouse E (ed) Genetics, biofuels and local farming systems. Sustainable agriculture reviews, vol 7. Springer, Netherlands, pp 161-214

Álvarez-Fernández A, Abadía J, Abadía A (2006) Iron deficiency, fruit yield and fruit quality. In: Barton LL, Abadía J (eds) Iron nutrition in plants and rhizospheric microorganisms. Springer, Dordrecht, pp 85-101

Briat JF, Curie C, Gaymard F (2007) Iron utilization and metabolism in plants. Curr Opin Plant Biol 10:276-282

Budzikiewicz H (2010) Microbial siderophores. In: Kinghorn AD, Falk H, Kobayashi J (eds) Progress in the chemistry of organic natural products. Fortschritte der chemie organischer naturstoffe/progress in the chemistry of organic natural products, vol 92. Springer, Vienna, pp 1-75

Campbell JK, Erdman JW (2005) Tomato, lycopene, and prostate cancer. In: Bendich A, Deckelbaum RJ (eds) Preventive nutrition. Nutrition and health. Humana Press, Totowa, pp 157-170

Cesco S, Nikolic M, Römheld V, Varanini Z, Pinton R (2002) Uptake of $59 \mathrm{Fe}$ from soluble $59 \mathrm{Fe}$-humate complexes by cucumber and barley plants. Plant Soil 241:121-128

Chander K, Hartmann G, Joergensen RG, Khan KS, Lamersdorf $N$ (2008) Comparison of methods for measuring heavy metals and total phosphorus in soils contaminated by different sources. Arch Agron Soil Sci 54:413-422

Crowley DE, Römheld V, Marschner H, Szaniszlo PJ (1992) Root-microbial effects on plant iron uptake from siderophores and phytosiderophores. Plant Soil 142:1-7

De Vleesschauwer D, Djavaheri M, Bakker PAHM, Höfte M (2008) Pseudomonas fluorescens WCS374r-induced systemic resistance in rice against Magnaporthe oryzae is based on pseudobactin-mediated priming for a salicylic acid-repressible multifaceted defense response. Plant Physiol 148:1996-2012

Desai A, Archana G (2011) Role of siderophores in crop improvement. In: Maheshwari DK (ed) Bacteria in agrobiology: plant nutrient management. Springer, Berlin, pp 109-139

Duffy BK, Défago G (1999) Environmental factors modulating antibiotic and siderophore biosynthesis by Pseudomonas fluorescens biocontrol strains. Appl Environ Microbiol 65:2429-2438

Fernández V, Ebert G, Winkelmann G (2005) The use of microbial siderophores for foliar iron application studies. Plant Soil 272:245-252

Godsey CB, Schmidt JP, Schlegel AJ, Taylor RK, Thompson CR, Gehl RJ (2003) Correcting iron deficiency in corn with seed row-applied iron sulfate. Agron J 95:160-166

Guerinot M (2010) Iron. In: Hell R, Mendel R-R (eds) Cell biology of metals and nutrients. Plant cell monographs, vol 17. Springer, Berlin, pp 75-94 
Hider RC, Kong X (2010) Chemistry and biology of siderophores. Nat Prod Rep 27:637-657

Hördt W, Römheld V, Winkelmann G (2000) Fusarinines and dimerum acid, mono- and dihydroxamate siderophores from Penicillium chrysogenum, improve iron utilization by strategy I and strategy II plants. Biometals 13:37-46

Johnson GV, Lopez A, La Valle Foster N (2002) Reduction and transport of Fe from siderophores. Plant Soil 241:27-33

Kaparullina EN, Doronina NV, Trotsenko YA (2011) Aerobic degradation of ethylenediaminetetraacetate. Appl Biochem Microbiol 47:460-473

Kari FG, Giger W (1995) Modeling the photochemical degradation of ethylenediaminetetraacetate in the River Glatt. Environ Sci Tech 29:2814-2827

Lichtenthaler HK, Buschmann C (2001) Extraction of photosynthetic tissues: chlorophylls and carotenoids. Curr Protoc Food Analyt Chem:F4.2.1-F4.2.6

Meziane H, Van Der Sluis I, Van Loon LC, Höfte M, Bakker PAHM (2005) Determinants of Pseudomonas putida WCS358 involved in inducing systemic resistance in plants. Mol Plant Pathol 6:177-185

Neilands JB (1995) Siderophores: structure and function of microbial iron transport compounds. J Biol Chem 270:26723-26726

Nikolic M, Cesco S, Römheld V, Varanini Z, Pinton R (2007) Short-term interactions between nitrate and iron nutrition in cucumber. Funct Plant Biol 34:402-408

Orera I, Abadía J, Abadía A, Álvarez-Fernández A (2009) Analytical technologies to study the biological and environmental implications of iron-fertilisation using synthetic ferric chelates: the case of $\mathrm{Fe}(\mathrm{III})-\mathrm{EDDHA}$ - a review. J Hortic Sci Biotechnol 84:7-12

Peleg Z, Blumwald E (2011) Hormone balance and abiotic stress tolerance in crop plants. Curr Opin Plant Biol 14:290-295

Rainey PB (1999) Adaptation of Pseudomonas fluorescens to the plant rhizosphere. Environ Microbiol 1:243-257

Ramos Solano B, Barriuso J, Gutiérrez Mañero FJ (2008) Physiological and molecular mechanisms of plant growth promoting rhizobacteria (PGPR). In: Plant-bacteria interactions. Wiley, Weinheim, pp 41-54

Ramos-Solano B, García JAL, Garcia-Villaraco A, Algar E, Garcia-Cristobal J, Mañero FJG (2010) Siderophore and chitinase producing isolates from the rhizosphere of
Nicotiana glauca Graham enhance growth and induce systemic resistance in Solanum lycopersicum L. Plant Soil 334:189-197

Raymond K, Müller G, Matzanke B (1984) Complexation of iron by siderophores a review of their solution and structural chemistry and biological function. Top Curr Chem 123:49-102

Rombolá A, Tagliavini M (2006) Iron nutrition of fruit tree crops. In: Barton LL, Abadía J (eds) Iron nutrition in plants and rhizospheric microorganisms. Springer, Dordrecht, pp 61-83

Römheld V, Marschner H (1986) Evidence for a specific uptake system for iron phytosiderophores in roots of grasses. Plant Physiol 80:175-180

Schalk IJ, Hannauer M, Braud A (2011) New roles for bacterial siderophores in metal transport and tolerance. Environ Microbiol 13:2844-2854

Schwyn B, Neilands JB (1987) Universal chemical assay for the detection and determination of siderophores. Anal Biochem 160:47-56

Shenker M, Chen Y (2005) Increasing iron availability to crops: fertilizers, organo-fertilizers, and biological approaches. Soil Sci Plant Nutr 51:1-17

Tan HL, Thomas-Ahner JM, Grainger EM, Wan L, Francis DM, Schwartz SJ, Erdman JW Jr, Clinton SK (2010) Tomatobased food products for prostate cancer prevention: what have we learned? Cancer Metastasis Rev 29:553-568

Tomasi N, Rizzardo C, Monte R, Gottardi S, Jelali N, Terzano R, Vekemans B, de Nobili M, Varanini Z, Pinton R, Cesco S (2009) Micro-analytical, physiological and molecular aspects of $\mathrm{Fe}$ acquisition in leaves of Fe-deficient tomato plants re-supplied with natural Fe-complexes in nutrient solution. Plant Soil 325:25-38

Vempati RK, Loeppert RH (1988) Chemistry and mineralogy of Fe-containing oxides and layer silicates in relation to plant available iron. J Plant Nutr 11:1557-1574

Yi Y, Saleeba J, Guerinot ML (1994) Iron uptake in Arabidopsis thaliana. In: Manthey J, Luster D, Crowley DE (eds) Biochemistry of metal micronutrients in the rhizosphere. CRC Press, Boca Raton, pp 295-307

Zuo Y, Zhang F (2011) Soil and crop management strategies to prevent iron deficiency in crops. Plant Soil 339:83-95 